\title{
Yield mapping of arabic coffee and their relationship with plant nutritional status
}

\author{
S.A. Silva ${ }^{1 *}$, J.S.S. Lima², E.L. Bottega ${ }^{3}$ \\ ${ }^{1}$ Department of Agricultural and Environmental Sciences, State University of Santa Cruz, Zip Code 45662-900, Bahia, \\ Brazil. ${ }^{2}$ Department of Agricultural Engineering, Federal University of Espirito Santo, Zip-Code 29500-000, Espirito Santo, \\ Brazil. ${ }^{3}$ Department of Agricultural Engineering, Federal University of Viçosa, Zip-Code 36570-000, Minas Gerais, Brazil. \\ "Corresponding author: sasilva@uesc.br
}

\begin{abstract}
The aim of this study was to model the spatial variability of the nutritional status of arabic coffee using leaf macro and micronutrient contents and relate it to drop in bean yield, bark percentage and crop yield. The experiment was conducted in a plantation of arabic coffee variety Catuaí located in the Zona da Mata of Minas Gerais State. Leaf nutrient contents, cherry coffee production, drop in bean yield, yield of benefited coffee and bark percentage were determined. Data were analyzed using classical statistical methods to find the relationship between nutrients and yield variables and then examined by geostatistical analysis. The yield variables and leaf nutrients that were found related showed spatial dependence without random distribution. Nutritional imbalance was detected in the studied coffee crop expressed by the deficiency or excess of some nutrients in the plant tissue. Ca provided the smallest drop in bean yield while the leaf contents of $\mathrm{B}$ and $\mathrm{Zn}$ had an opposite effect on the production and yield of coffee.
\end{abstract}

Keywords: precision agriculture, mineral nutrition, Coffea arabica, geostatistics

\section{Introduction}

The growing nutrient demand by increasingly productive coffee cultivars and the expansion of crops to low fertility soils require a better understanding of the nutrient dynamics in the crop (Reis Jr. and Martinez, 2002). This information helps avoid nutritional deficiency problems that greatly affect the efficiency of fertilization and significantly reduce production.

The large nutrient export by the coffee crop and high fertilizer prices have made the monitoring of nutritional status using leaf analysis essential to provide more balanced and cost-effective fertilizer recommendations (Valarini et al., 2005). To achieve high yields, adequate fertilizer applications should be based mainly on limiting nutrients and also in the nutritional diagnosis of the plant (Silva et al., 2012).

Farnezi et al. (2010) argue that the greatest advantage in studying plant nutrition is to consider the plant itself as an extractor and to allow a direct evaluation of its nutritional status, assessing the contents and 
the relationships between nutrients. Because the coffee tree has a high nutrient demand, mainly for flowering and fruit-setting, the nutritional imbalance will compromise significantly the bean yield and crop productivity (Furlani Jr. and Paul, 2010).

A high ratio of fresh cherry to processed coffee (lower yield) directly affects the final profitability of the production system (Silva et al., 2010a). Medina Filho and Bordignon (2003) discussed that reducing bean yield will lead to the real risk of the operating cost be equivalent to the revenue from the product sale, resulting in the financial unsustainability of the productive system.

Considering the need for quantitative and qualitative improvements of coffee production, new methods for increasing the efficiency of production systems must be proposed and new techniques to manage crop nutrition must be used (Lima et al., 2013). The geostatistics appears as a potential tool to help reduce losses caused by inappropriate management that result in low productivity (Flowers et al., 2005).

Geostatistical analysis has been useful in agricultural sciences to characterize and map the spatial variation of yield variables (Manzione et al., 2002). The assessment of the spatial variability of coffee nutrition is important for determining management strategies to meet the plant demands and achieve satisfactory production (Silva et al., 2010a).

From the foregoing, therefore, the aim of this study was to model the spatial variability of the nutritional status of coffee trees using macro and micronutrient contents of leaves and relate it to drop in bean yield, bark percentage and crop yield of Arabica coffee in eastern Minas Gerais, Brazil.

\section{Materials and Methods}

The study was conducted in a plantation of Coffea arabica L. in the Zona da Mata of Minas Gerais, with averages geographical coordinates of $20^{\circ} 45^{\prime} 45.4^{\prime} \mathrm{S}$ latitude and $41^{\circ} 32^{\prime} 9.75^{\prime \prime} \mathrm{W}$ longitude.

The area has been cultivated with variety Catuaí in the spacing $2.0 \times 0.6 \mathrm{~m}$ for five years. The soil is a humic Red Yellow Latosol with A horizon very thick and rich in organic matter.

Sampling was carried out in a regular grid of approximately 0.8 ha, containing 50 sampling points, enough to meet the assumptions of variogram stability recommended by Kerry \& Oliver (2008). Each sampling point, with area of $6 \mathrm{~m} 2$, consisted of 3 coffee trees composing 3 subsamples, which were mixed to form a composite sample representative of the point.

The evaluations were performed during the agricultural year 2007/2008. Leaves of each sampling point were collected in early December 2007 for assessment of nutritional status. Leaves of the third and fourth pair of plagiotropic branches in the four cardinal directions on each plant from each sampling point were collected to determine the contents of macro ( $\mathrm{N}, \mathrm{P}, \mathrm{K}, \mathrm{Ca}, \mathrm{Mg}$ and $\mathrm{S}$ in dag $\mathrm{kg}^{-1}$ ) and micronutrients ( $\mathrm{Fe}, \mathrm{Mn}, \mathrm{Cu}, \mathrm{Zn}$ and $\mathrm{B}$ in $\mathrm{mg} \mathrm{kg}^{-1}$ ) as described by EMBRAPA (1997).

The production was evaluated in July 2008. For this purpose, the mass of cherry coffee harvested from the three plants in the sampling point was determined. A sample of $1.0 \mathrm{~kg}$ of fresh cherry was placed in an oven at $70{ }^{\circ} \mathrm{C}$ to reach about $12 \%$ of moisture content. After drying, the bark was removed, leaving only the raw coffee, which was called benefited coffee. Then, the drop in yield (QRend) (fresh cherry/ benefited coffee), the bark percentage and the conversion of green coffee production per hectare were calculated.

Exploratory data analysis was carried out to verify the presence of outliers and their influence on the measures of position and dispersion. Then, the data were examined by measures of position (mean and median), dispersion (maximum, minimum, standard deviation, variance and coefficient of variation), measures of dispersion (coefficient of skewness and kurtosis) and 
correlation between leaf nutrient contents and yield variables. Normality was tested by the Shapiro-Wilk's test. The classical statistical analyzes were performed using the software Statistica 7.0.

To verify the existence of spatial dependence of the parameters and, if so, to quantify its degree, we carried out a geostatistical analysis by fitting theoretical functions to the models of experimental variograms based on the assumption of stationarity of the intrinsic hypothesis and according to the equation:

$$
\gamma^{*}(h)=\frac{1}{2 N(h)} \sum_{i=1}^{N(h)}\left[z\left(x_{i}\right)-z\left(x_{i}+h\right)\right]^{2}
$$

where: $N(h)$ is the number of pairs of the values $[Z(x i)$, $\mathrm{Z}(\mathrm{xi}+\mathrm{h})$ ] separated by a vector $\mathrm{h}$ and $\mathrm{xi}$ is a spatial position of the variable $\mathrm{Z}$. A mathematical function fits the point cloud $\left[\mathrm{h}, \mathrm{y}^{*}(\mathrm{~h})\right]$ and have parameters known as nugget effect $\left(\mathrm{C}_{0}\right)$, which corresponds to the intersection on the axis of the semivariances; sill $\left(\mathrm{C}_{0}\right.$ $+\mathrm{C}$ ), which is approximately equal to the variance of the data; and range (a), which represents the distance at which the variogram reaches the sill. Depending on the behavior of the semivariance $y^{*}(\mathrm{~h})$ for high values of $h$, the models can be classified into: models with sill, which represent the second-order stationarity, and models without sill that satisfy only the intrinsic hypothesis and variograms can be defined, but do not stabilize at any sill level.

The model was chosen based on the minimization of the sum of squared errors and the coefficient of multiple determination $\left(\mathrm{R}^{2}\right)$ of the adjustment of a variogram theoretical model to the empirical model. The $\mathrm{R}^{2}$ of the cross validation (observed values versus estimated values) was also used as a criterion of choice.

The spatial dependence index (SDI) was analyzed using the ratio $\mathrm{C}_{0} /\left(\mathrm{C}_{0}+\mathrm{C}\right)$ and the intervals proposed by Cambardella et al. (1994) who considered (SDI $<25 \%$ ) as strong spatial dependence, $(25 \% \leq \mathrm{SDI}<75 \%)$ as moderate and $(\mathrm{SDI} \geq 75 \%)$ as weak.
The variograms used in this work were scaled by the variance of the data to facilitate their comparison. Once the existence of spatial dependence defined by the variogram was confirmed, values for any location where the variable was not measured were estimated using ordinary kriging, which estimates values without trend and with minimal deviations in relation to the known values, ie, with minimal variance.

The geostatistical analyses and the making of thematic maps were performed using the software of geographical information system ArcGIS 9.3.

\section{Results and Discussion}

The results of the descriptive statistics, excluding the outliers, show that except for $\mathrm{Mg}, \mathrm{Fe}, \mathrm{Mn}$ and $\mathrm{Cu}$, all leaf nutrients and yield variables had very close measures of central tendency (mean and median) (Table 1).

The attributes in which these measures were different had the asymmetry values distant from zero showing deviation from the normal distribution. In this case, the asymmetry values were positive, with tendency of concentrating data to the right, with mean values greater than the median. Magnesium is an exception, because it showed asymmetry values close to zero, but deviates itself from the normal distribution due to the high negative kurtosis.

The other attributes and variables had coefficients of skewness near zero, suggesting an adjustment to the normal distribution, which was confirmed by the Shapiro-Wilk's test at $5 \%$ probability. According to Webster and Oliver (2007), data normality is a requirement for geostatistical models when using probabilistic estimation models as in indicative kriging, in other cases it is only expected that the tails of the normal distribution are not very long. 
Table 1. Descriptive statistics and frequency distribution of foliar nutrients and yield variables.

\begin{tabular}{cccccccccc}
\hline \multirow{2}{*}{ Variables $^{(1)}$} & \multicolumn{9}{c}{ Statistics $^{(2)}$} \\
\cline { 2 - 11 } & Mean & Median & Minimum & Maximum & $\mathrm{s}$ & $\mathrm{CV}(\%)$ & $\mathrm{Cs}$ & $\mathrm{Ck}$ & $\mathrm{W}$ \\
\hline $\mathrm{N}$ & 3.23 & 3.24 & 2.57 & 3.94 & 0.34 & 10.43 & 0.10 & -0.28 & ns \\
$\mathrm{P}$ & 0.14 & 0.15 & 0.08 & 0.23 & 0.03 & 23.59 & 0.17 & -0.17 & ns \\
$\mathrm{K}$ & 1.22 & 1.20 & 0.85 & 1.65 & 0.17 & 14.14 & 0.34 & 0.13 & ns \\
$\mathrm{Ca}$ & 1.01 & 0.99 & 0.69 & 1.29 & 0.15 & 15.05 & 0.30 & -0.29 & ns \\
$\mathrm{Mg}$ & 0.24 & 0.20 & 0.17 & 0.33 & 0.05 & 22.10 & 0.09 & -1.14 & $*$ \\
$\mathrm{~S}$ & 0.08 & 0.08 & 0.05 & 0.11 & 0.01 & 14.97 & 0.27 & 0.00 & ns \\
Zn & 7.75 & 7.85 & 4.10 & 10.60 & 1.76 & 22.74 & -0.25 & -0.67 & ns \\
Fe & 89.24 & 84.85 & 51.60 & 149.60 & 23.48 & 26.31 & 0.70 & -0.14 & $*$ \\
Mn & 133.04 & 126.00 & 84.90 & 215.50 & 34.68 & 26.07 & 0.66 & -0.47 & $*$ \\
Cu & 34.25 & 32.45 & 10.95 & 72.45 & 16.16 & 47.19 & 0.56 & -0.63 & $*$ \\
B & 53.22 & 52.30 & 41.20 & 67.10 & 6.03 & 11.32 & 0.33 & -0.29 & ns \\
Cherry Coffee & 30.60 & 31.67 & 10.56 & 52.50 & 9.65 & 31.55 & -0.09 & -0.17 & ns \\
Benefited coffee & 6.60 & 6.95 & 2.06 & 10.46 & 1.97 & 29.87 & -0.25 & 0.01 & ns \\
QRend & 4.63 & 4.58 & 3.97 & 5.25 & 0.30 & 6.54 & -0.11 & -0.48 & ns \\
\% Bark & 17.86 & 17.54 & 14.04 & 21.59 & 1.82 & 10.21 & -0.01 & -0.73 & ns \\
\hline
\end{tabular}

${ }^{(1)} \mathrm{N}, \mathrm{P}, \mathrm{K}, \mathrm{Ca}, \mathrm{Mg}$ and $\mathrm{S}$ in the dag $\mathrm{kg}^{-1}$; Zn, Fe, Mn, Cu, B in the mg.kg-1; QRend: drop in yield. ${ }^{(2)}$ s: standard deviation; CV (\%): coefficient of variation; Cs: asymmetry; Ck: kurtosis. * Non-normal distribution of the test Shapiro-Wilk's in the 5\% of the

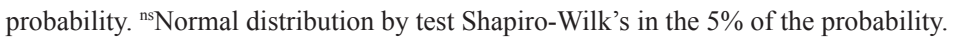

The coefficient of variation (CV) showed that, according to the classification used by Silva et al. (2012), except for $\mathrm{N}$ (low), the other attributes showed average variation.

It is considered that the crop has nutritional imbalance when the mean values of $\mathrm{N}, \mathrm{K}, \mathrm{Mg}, \mathrm{S}, \mathrm{Cu}$ and $\mathrm{Zn}$ are distant from the recommended, while the levels of $\mathrm{P}, \mathrm{Ca}, \mathrm{Fe}, \mathrm{Mn}$ and $\mathrm{B}$ are adequate (Ribeiro et al., 1999). Silva et al. (2010b) point out that the nutritional imbalance of coffee trees can lead to a decrease in yield, with loss of berries by malformation and also the increase in the drop in bean yield.
The correlation between leaf nutrients and the yield variables (Table 2) indicate that, in our case, not all nutrients have a significant relationship with yield. Silva et al. (2010a) working with coffee found similar results, attributing this behavior to the joint action of elements that account for crop yield.

Production of both fresh cherry and green coffee was positively correlated with leaf $\mathrm{Zn}$ contents and negatively with leaf $\mathrm{B}$ contents. Leaf $\mathrm{Ca}$ contents were negatively correlated with QRend, while leaf $\mathrm{K}$ contents were positively correlated with the bark percentage. 
Table 2. Linear correlation between foliar nutrients and yield variables.

\begin{tabular}{ccccc}
\hline \multirow{2}{*}{ Variables } & \multicolumn{4}{c}{ Variables } \\
\cline { 2 - 5 } & Cherry Coffee & Benefited coffee & QRend & $\%$ Bark \\
\hline $\mathrm{N}$ & -0.19 & -0.19 & -0.07 & 0.12 \\
$\mathrm{P}$ & -0.09 & -0.06 & -0.12 & 0.01 \\
$\mathrm{~K}$ & -0.29 & -0.23 & 0.18 & $0.45^{* *}$ \\
$\mathrm{Ca}$ & -0.28 & -0.21 & $-0.47^{* *}$ & 0.10 \\
$\mathrm{Mg}$ & -0.16 & -0.14 & -0.27 & -0.01 \\
$\mathrm{~S}$ & -0.11 & -0.09 & -0.19 & -0.14 \\
$\mathrm{Zn}$ & $0.38^{* *}$ & $0.41^{* *}$ & -0.02 & -0.11 \\
$\mathrm{Fe}$ & -0.18 & -0.16 & -0.17 & 0.18 \\
$\mathrm{Mn}$ & -0.16 & -0.19 & 0.09 & -0.04 \\
$\mathrm{Cu}$ & 0.21 & 0.24 & -0.06 & -0.07 \\
$\mathrm{~B}$ & $-0.48^{* *}$ & $-0.51^{* *}$ & 0.04 & 0.18 \\
\hline
\end{tabular}

** Correlation significant at $1 \%$ probability.

$\mathrm{K}$ has the highest concentrations in coffee barks because of its accumulation during the stages of bean formation and filling. This material is often used as a source of natural fertilizer for the replacement of $\mathrm{K}$ levels in the soil (Soares et al . 2005).

The geostatistical analysis was performed for the yield variables and only for the nutrients that were correlated with these variables (Table 3 ).

All variables and nutrients showed spatial dependence and the spherical model was the best fit to the data, except for $\mathrm{Zn}$ which fit the exponential model. Souza et al. (2004) argue that the spherical model is the best to describe the variability of the soil-plant system attributes, because they generally have a well-defined spatial behavior with well-established ranges.

The analysis of the spatial variability using the range effect showed that B is the nutrient with the greatest variability and QRend with the lowest variability.
The range of spatial dependence is an important parameter in the study of the variogram (Flowers et al. 2005) because it indicates the area of influence of a sample, i.e., it defines the maximum distance in which a variable has spatial dependence with its neighbor (Taylor et al., 2007).

The semi-variance range represents the limit of the spatial continuity of a phenomenon, this being the greater as the larger is the range (Kerry and Oliver, 2008). Webster \& Oliver (2007) state that variograms with large ranges tend to increase the accuracy of estimates using mainly the ordinary kriging. The authors discuss that these results favor the interpretation of thematic maps and consequently favor the sitespecific management of agricultural production areas.

Based on the classification of Cambardella et al. (1994), $\mathrm{Ca}, \mathrm{B}$, fresh cherries, green coffee and bark percentage high SDI, while $\mathrm{K}, \mathrm{Zn}$ and yield had medium SDI. 
Table 3. Models and parameters of the average variograms for the foliar nutrients and yield variables.

\begin{tabular}{cccccccc}
\hline \multirow{2}{*}{ Variables } & \multicolumn{7}{c}{ Models and Parameters } \\
\cline { 2 - 7 } & Model & $\mathrm{C}_{0}$ & $\mathrm{C}_{0}+\mathrm{C}$ & $\mathrm{A}_{0}$ & $\mathrm{R}^{2}$ & $\mathrm{SDI}$ & $\mathrm{R}^{2}(\mathrm{VC})$ \\
\hline $\mathrm{K}$ & Spherical & 0.51 & 1.16 & 16 & 64 & 43 & 32.3 \\
$\mathrm{Ca}$ & Spherical & 0.05 & 0.77 & 15 & 89 & 06 & 34.5 \\
Zn & Exponential & 0.24 & 0.82 & 15 & 74 & 29 & 25.4 \\
$\mathrm{~B}$ & Spherical & 0.22 & 0.89 & 9 & 43 & 24 & 28.7 \\
Cherry Coffee & Spherical & 0.02 & 0.96 & 17 & 83 & 03 & 39.6 \\
Benefited coffee & Spherical & 0.12 & 1.02 & 17 & 75 & 12 & 39.6 \\
QRend & Spherical & 0.37 & 1.01 & 32 & 71 & 37 & 29.9 \\
\% Bark & Spherical & 0.07 & 1.09 & 17 & 84 & 06 & 29.3 \\
\hline
\end{tabular}

${ }^{(1)} \mathrm{C}_{0}$ : nugget effect; $\mathrm{C}_{0}+\mathrm{C}$ : sill; $\mathrm{A}_{0}$ range; $\mathrm{R}^{2}$ : determination coefficient; $\mathrm{SDI}$ : spatial dependence index $(\%)$; $\mathrm{R}^{2}(\mathrm{VC})$ : determination coefficient of the cross validation.

These spatial dependence indices are explained mainly by the $\mathrm{C} 0$ values, which were proportionally medium for those with medium SDI, and low for those with high SDI.

After the definition of the models and parameters for the variograms, the data were interpolated by ordinary kriging to map the leaf nutrients and the yield variables (Figure 1).

The correlations (Table 2) become evident by observing the thematic maps (Figure 1) of the variables and nutrients assessed in the study.

Areas with higher $\mathrm{Zn}$ levels also have the highest production of fresh cherries and green coffee. $\mathrm{Zn}$ is highly demanded for the synthesis of essential amino acids that are precursors of the indole acetic acid (IAA), which induces branch elongation. Zinc deficiency causes reduction in internodes, smaller leaves, rosettes formation, low dry matter production, affects filling and bean size and consequently the final yield (Tomaz et al. 2011).
Yields are higher where the B levels are lower, showing an interaction between $\mathrm{Zn}$ and $\mathrm{B}$ and indicating that the $\mathrm{Zn}$ availability is higher in plants with lower B leaf contents. According to Epstein and Bloom (2006) and Malavolta et al. (2002), nutrients are able to interact with each other interfering with their assimilation and utilization.

Ca contents were negatively correlated with QRend. It was found that the north side of the coffee tree has the highest $\mathrm{Ca}$ contents and, consequently, the lowest QRend. This indicates a direct relationship between the amounts of $\mathrm{Ca}$ in the leaves and a smaller drop in bean yield.

Ca contributes significantly to a lower ratio of fresh cherry to benefited coffee. Vitti et al. (2006) argued that $\mathrm{Ca}$ is directly related to biomass accumulation in plants because of its physiological role in important pathways, directly affecting the bean yield. 
The positive influence of $\mathrm{K}$ on bark percentage was expected. Unlike the beans that tend to accumulate more nitrogen, phosphorus, magnesium and sulfur, the coffee bark accumulates mainly calcium and potassium (Valarini et al. 2005).
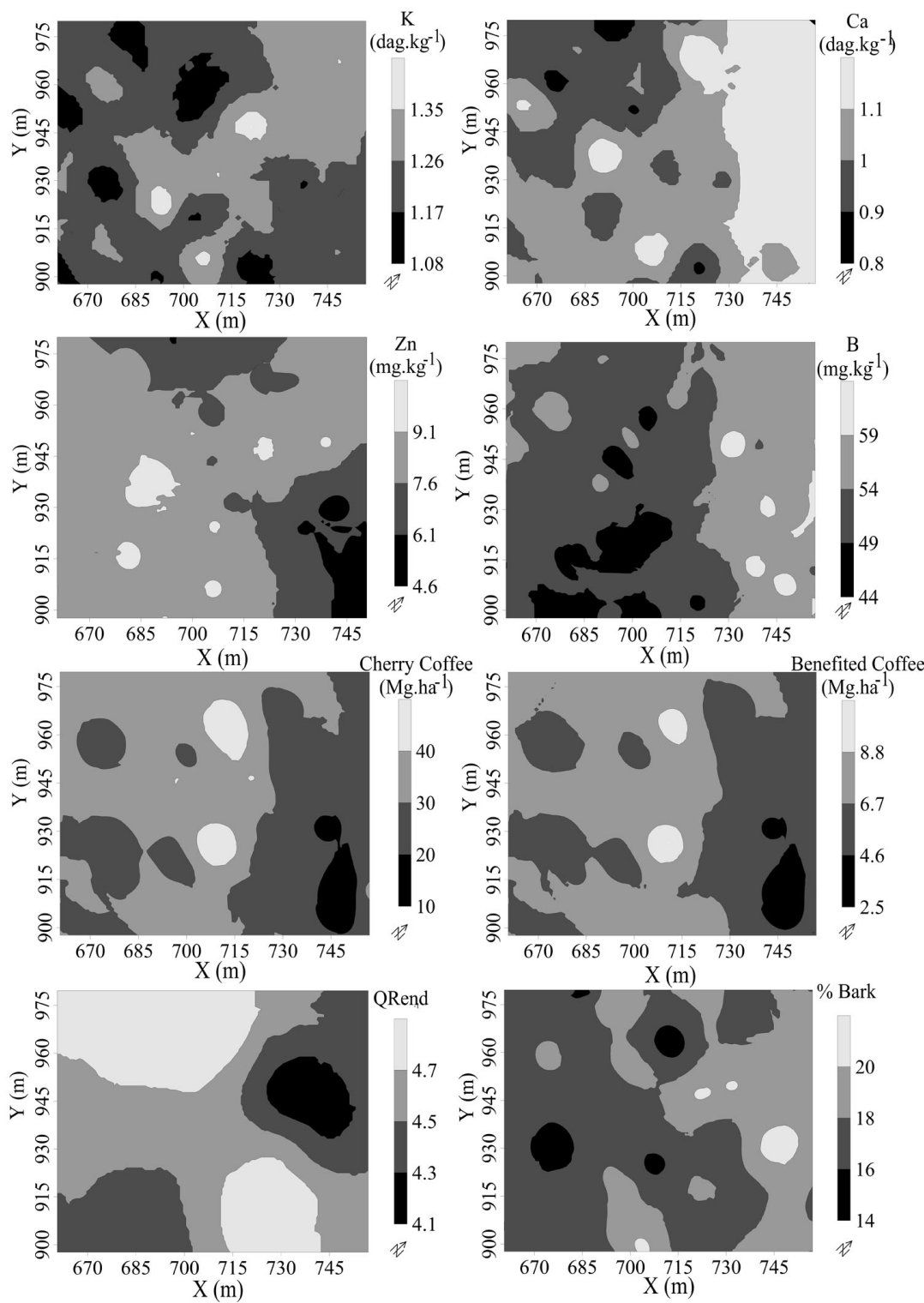

Figure 1. Thematic maps for the leaf nutrients and for the yield variables. 


\section{Conclusions}

Spatial analysis techniques allowed the assessment of the spatial behavior of the crop and helped to identify areas of specific management for each element involved in the study. This study was conducted at the local level with a 99\% confidence level and identified a statistically significant spatial relationship between $\mathrm{K}$, $\mathrm{Ca}, \mathrm{Zn}$ and $\mathrm{B}$ leaf contents and yield variables.

Our results provide guidance on how best to manage the coffee crop and achieve higher yields and smaller drops in bean yield. Using this methodology, it is possible to change the balance between leaf nutrients and reach levels of no deficiency through fertilization practices guided by thematic maps for each element, but especially for those that are correlated with yield variables.

Ca provided the smallest drop in bean yield, while the leaf contents of $\mathrm{B}$ and $\mathrm{Zn}$ showed opposite behavior in terms of production and yield of coffee, which is explained by the adequate leaf concentration of the former and the deficiency of the latter.

The spatial analysis allowed the assessment of the nutritional status of the coffee trees considering the spatial variability that exists in the crop field. It also supplied information to understand the performance of the crop in the area and to promote actions to avoid this problem. In this study, excess and deficiency of some nutrients contributed to lower coffee yield.

\section{References}

Cambardella, C.A.; Moorman, T.B.; Novak, J.M.; Parkin, T.B.; Karlen, D.L.; Turco, R.F. \& Konopka, A.E. 1994. Field-scale variability of soil properties in Central Iowa soils. Soil Science Society American Journal. 58, 1501-1511.

Embrapa Empresa Brasileira de Pesquisa Agropecuária. Centro Nacional de Pesquisa de
Solo. 1997. Manual de métodos de análise de solo. $2^{\text {a }}$ ed. Rio de Janeiro, EMBRAPA. Serviço Nacional de Levantamento e Conservação de Solo. 212p.

Epstein, E., Bloom, A.J. 2006. Nutrição mineral de plantas: princípios e perspectivas. Planta Editora. 2 ed. 403.

Farnezi, M.M.M.; Silva, E.B.; Guimaraes, P.T.E.; Pinto, N.A.V.D. 2010. Levantamento da qualidade da bebida do café e avaliação do estado nutricional dos cafeeiros do Alto Jequitinhonha, Minas Gerais, através do DRIS. Ciência e Agrotecnologia. 34, 1191-1198.

Flowers, M., Weisz, R., White, J.G..2005. Yield-based management zones and gridsampling strategies: Describing soil tests and nutrient availability. Agronomy Journal. 97, 968-982.

Kerry, R., Oliver, M.A. 2008. Determining nugget: sill ratios of standardized variograms from aerial photographs to krige sparse soil data. Precision Agriculture. 9, 33-56.

Lima, J.S.S.; Silva, S.A.; Silva, J.M. 2013. Variabilidade espacial de atributos químicos de um Latossolo Vermelho-Amarelo cultivado em plantio direto. Revista Ciência Agronômica, 44, 1, 16-23.

Malavolta, E., Favarin, J.L., Malavolta, M., Cabral, C.P., Heinrichs, R., Silveira, J.S.M. 2002. Repartição de nutrientes nos ramos, folhas e flores do cafeeiro. Pesquisa Agropecuária Brasileira. 37, 1017-1022

Manzione, R.L.; Rodrigues, J.B.T.; Zimback, C.R.L. 2002. Análise espacial multivariada na avaliação de parâmetros químicos do solo. 23p. 2002. In: Balastreire, L. A. Avanços na Agricultura de Precisão no Brasil no período de 1999-2001. Piracicaba, 347. 
Medina Filho, H.P., Bordignon, R. 2003. Rendimento Intrínseco: um critério adicional para selecionar cafeeiros mais rentáveis. O Agronômico. 55, 24-26.

Paulo, E.M., Furlani Jr., E. 2010. Yield performance and leaf nutrient levels of Coffee cultivars under different plant densities. Scientia Agricola. 67, 720-726.

Reis Jr, R.A., Martinez, H.E.P. 2002. Adição de Zn e absorção, translocação e utilização de $\mathrm{Zn}$ e P por cultivares de cafeeiro. Scientia Agricola. 59, 537-542.

Ribeiro, A.C.,Guimarães, P.T.G. and Alvarez V.H.V., eds. 1999. Recomendações para uso de corretivos e fertilizantes em Minas Gerais. $5^{\mathrm{a}}$ Aproximação. Viçosa, MG, Comissão de Fertilidade do Solo do Estado de Minas Gerais - CFSEMG, 359.

Silva, S.A., Lima, J.S.S. 2012. Multivariate analysis and geostatistics of the fertility of a humic rhodic hapludox under coffee cultivation. Revista Brasileira de Ciência do Solo. 36, 2, 467-474.

Silva, S.A., Lima, J.S.S., Alves, A.I. 2010b. Estudo espacial do rendimento de grãos e porcentagem de casca de duas variedades de Coffea arabica L. visando a produção de café de qualidade. Bioscience Journal. 26, 558-565.

Silva, S.A., Lima, J.S.S., Souza, G.S. 2010a. Estudo da fertilidade de um Latossolo Vermelho-Amarelo húmico sob cultivo de café arábica por meio de geoestatística. Revista Ceres. 57, 560-567.
Soares, A.R., Mantovani, E.C., Rena, A.B., Soares, A.A. 2005. Irrigação e fisiologia da floração em cafeeiros adultos na região da zona da mata de Minas Gerais. Acta Scientiarum. Agronomy, 27, 117-125.

Souza, Z.M., Marques Júnior, J., Pereira, G.T., Moreira, L.F. 2004. Variabilidade espacial do $\mathrm{pH}, \mathrm{Ca}, \mathrm{Mg}$ e $\mathrm{V} \%$ do solo em diferentes formas do relevo sob cultivo de cana-de-açúcar. Ciência Rural. 34, 1763-1771.

Taylor, J.A., Mcbratney, A.B., Whelan, B.M. 2007. Establishing management classes for broadacre agricultural production. Agronomy Journal. 10, 1366-1376.

Tomaz, M.A., Martinez, H.E.P., Rodriguez, W.N., Ferrari, R.B., Pereira, A.A., Sakiyama, N.S. 2011. Eficiência de absorção e utilização de boro, zinco, cobre e manganês em mudas enxertadas de cafeeiro. Revista Ceres. 58, 108-114.

Valarini, V.. Bataglia, O.C., Fazuoli, L.C. 2005. Macronutrientes em folhas e frutos de cultivares de café arábica de porte baixo. Bragantia. 64, 61-67.

Vitti, G.C., Lima, E., Cicarone, F. 2006. Cálcio, magnésio e enxofre. In: Fernandes, M. S. Nutrição mineral de plantas. Viçosa, MG: Sociedade Brasileira de Ciência do Solo. 299-326.

Webster, R., Oliver, M.A. 2007. Geostatistics for environmental scientists. 2 ed. John Wiley \$ Sons, Ltd. 333p. 